\title{
Effectiveness of the Addition of Kelakai (Stenochlaena palustris) Extracts in Commercial Pellet as Immunostimulant for Snakehead (Channa striata)
}

\author{
Norhayati", Indira Fitriliani, Untung Bijaksana, Ahmadi \\ Faculty of Marine and Fisheries, LambungMangkurat University, Banjarbaru 7014, Indonesia \\ *Corresponding Author: Ahmadi, Faculty of Marine and Fisheries, LambungMangkurat University, \\ Banjarbaru 7014, Indonesia
}

\begin{abstract}
This study was aimed at determining the best performance of the addition of Kelakai (Stenochlaena palustris) in commercial pellets as immunostimulant to increase the Snakehead's immune system. Sampling, extraction and measurement were carried out in the Wet Laboratory Faculty of Marine and Fisheries ULM and related institutions. A total of 240 individuals of Snakehead fingerlings (15-25 cm total length and 25-100 $g$ weight) subjected to different feeding levels were investigated in 12 circle containers. A complete random design was used as a research method with four treatments and three repetitions. Treatment A: $0 \mathrm{ml} / \mathrm{kg}$ of pellet (control), treatment B: $50 \mathrm{ml} / \mathrm{kg}$, treatment $C: 100 \mathrm{ml} / \mathrm{kg}$, and treatment D: $150 \mathrm{ml} / \mathrm{kg}$. The results showed that the survival rate of Snakehead samples reared in indoor containers was $100 \%$ for all treatments. The best performance for Snakehead was given by treatment $C$ in term of hemoglobin $(10.3 \pm 23.29 \mathrm{~g} / \mathrm{dl})$, hematocrit $(24.32 \pm 10.66 \%)$ and blood plasma $(75.68 \pm 10.66 \mathrm{~g} / \mathrm{ml})$. The iron compound in the tested feeds and in the fish meats of Snakehead were ranged of $24.35-28.01 \mathrm{mg} / \mathrm{kg}$ and $1.76-3.08 \mathrm{mg} / \mathrm{kg}$ respectively. Snakehead in treatments $A, B$ and $C$ showed negative allometric growth pattern $(b=1.89-2.48)$, while for treatment $D$ exhibited isometric growth pattern $(b=2.96)$. Water quality parameters were in tolerance range for fingerlings rearing period: temperature was $26.5-27.1{ }^{\circ} \mathrm{C}, \mathrm{pH} 6.3$ - 6.7, DO 4.1 - $5.1 \mathrm{ppm}$, and Ammonia 1.20- $2.88 \mathrm{mg} / \mathrm{l}$. This study is the first reference for assessing the effect of Kelakai extracts to the immunetriggering response in Snakehead. The outcome of research could be useful for aquaculture management system and pellet industry.
\end{abstract}

Keywords: Kelakai extract, Snakehead fingerling, hemoglobin, hematocrit, iron compound

\section{INTRODUCTION}

Snakehead (Channastriata) of family Channidae, is considered as important food source due to its delicate flesh, well-accepted flavour, its high nutritional and unique medicinal values, and also availability throughout the year. Like other labyrinth fish such as Climbing perch [1] and Kissing gourami [2],the snakehead is air-breathing fish and adaptable to extreme environmental change [3]. In nature, snakehead can be found in swamps, rivers, canals, lakes, and paddy fields[4,5,6,7], and can also be commercially cultured in earthen ponds,fish farm, cage nets or hapa system [8,9], including its business feasibility [10, 11]. Meanwhile, in Europe and North America, it is considered as an invasive species with high risks to aquatic ecosystems $[12,13]$.

For Kalimantan community, Snakehead locally called "Haruan" and becomes a favorite food at restaurant. Currently, supply and demand of snakehead are highly dependent on the catch from nature, meanwhile fish farming practices are still underdeveloped due to some technical barriers, inter-alia: (1) it is very difficult to acquire the superior fish seed, (2) the mortality rate of fish seed is relatively high, (3) the fish seed grows slowly and (4) it is also not easy to feed them at certain level. With this condition, fish farming business is considered not feasible and profitable. At the same time, the high price of snakehead boosting fishermen tried to increase the catch in order to meet the market demand. Overfishing, pollution and diseases may potentially threat to this species [14,15].If it is allowed it will affect to ecosystem and socio-economic as the whole, whereas the baseline information on the fish growth and exploitation rates is not available. For the time being, it is a great challenge for us to develop commercial fish farming of snakehead in this region. 
Some fundamental works have been done by the researchers to describe on biological aspects of snakehead, including food habits [16], extruded feed development [10], effect of feeding frequency[17],fish domestication [18], the restocking model [19], growth and survival rate[20],stocking density with recirculation system[21], gonad rematuration[22], population dynamic [15], the length-weight relationship and condition factor [23]. It is acknowledged that Snakehead is one of fish species that have not been domesticated perfectly resulted in fish are prone to stress. Under the circumstances, the stress level in the fish affects the body's endurance[19]. Stress is a non-specific biological phenomenon from an environmental change or other factors that affect the adaptability of homeostasis. The process of change will affect the physiological process which in turn can cause physical damage and even death[24]. It was confirmed that "Kelakai" (Stenochlaenapalustris) contains bioactive substances such as phenol, flavonoids, steroids, alkaloid and iron[25] that can be used as immunostimulantagent. It has been scientifically proven to increase immunity in the infected mice [26] or to determine the $\mathrm{LC}_{50}$ (Lethal Concentration 50\%) value for larval shrimp Artemiasalima Leach [27], but less common in fish including snakehead species. Therefore, the present study is performed to determine the best level of Kelakai's extract mixed with commercial pellet for increasing immunity in Snakehead fingerlings. By having this knowledge, we can improve the quality of current artificial pellet and increase the survival rate and growth.

\section{MATERIALS AND METHODS}

\subsection{Study Sites}

The researches were carried out in the Wet Laboratory belongs to Faculty of Marine and Fisheries LambungMangkurat University, South Kalimantan Province and PulangPisau District of Central Kalimantan Province, Indonesia.

\subsection{Snakehead and Kelakai samples}

A total of 240 individuals of Snakehead fingerlings (15-25 cm total length and 25-100 $\mathrm{g}$ weight) were obtained from the Peatland Fish Farming Installation located in Garung Village, Pulang Pisau District. While Kelakai (S. palustris) were collected from the swamp, which is abundantly found in this area. All samples were transported into the Wet Laboratory of the Faculty for further arrangement.

\subsection{Kelakai's extract}

The Kelakai plants were sun-dried, refined with blender, distillated and evaporated the solvent at $80^{\circ} \mathrm{C}$ using an electric stove. A $20 \mathrm{ml}$ of Kelakai extract was put into a bottle wrapped with aluminum foil, kept in the refrigerator and ready for use.

\subsection{The Mixed Feed Making}

Commercial pellet (LP-2 from PT. MatahariSakti) was refined with blender and weighted 1000 g/pack. The Kelakai extract was diluted by using distilled water with a ratio of 1:5 and then mixed with pellet flour. Stirred and added a little warm water to improve the feed mixture, and then milled them using a grinder and sun-dried. Pellet itself contains 33\% protein, $12 \%$ ash, $10 \%$ water, $5 \%$ fat and $4 \%$ crude fiber.

\subsection{Container Preparation}

A total of 12 circle containers (58 cm diameter, $23 \mathrm{~cm}$ high and $15 \mathrm{~cm}$ water height) were arranged and placed on the Laboratory floor, being prepared for Snake headrearing period. The upper part of container was covered with the nets to prevent Snakehead jump out of it.

\subsection{Sampling and Observation}

Sampling and measurement of Snakehead fingerlings were carried out three times: at the beginning, in the middle and the end of the study. Observations focused on survival rate, hematological analysis, iron (Fe) compound, and water quality and length-weight relationship of fish.

\subsection{Preliminary Research}

A preliminary test was performed to determine the Kalakai extract concentration to be used for Snakehead by feeding them with the mixed feed $(100 \mathrm{ml} / \mathrm{kg}$ pellet $)$ for 7-day rearing period and then the blood samples of fish were taken. It was done as basic information for treatment selection. 


\subsection{Experiment Design and Treatments}

A complete random design was used as a research method with four treatments and three repetitions (total 12 units).A series of experiments was done for a 60-day rearing period including sampling and measurements. The fingerling samples (20-fish per container) were fed twice a day ( 8 am and $5 \mathrm{pm})$ with different concentration of Kalakai extracts as follows:

- Treatment A: $0 \mathrm{ml} / \mathrm{kg}$ of pellet (control)

- Treatment B: $50 \mathrm{ml} / \mathrm{kg}$ of pellet

- Treatment C: $100 \mathrm{ml} / \mathrm{kg}$ of pellet

- Treatment D: $150 \mathrm{ml} / \mathrm{kg}$ of pellet

\subsection{Parameters Observed}

\subsubsection{Survival rate}

Survival rate (SR) is calculated using the following equation [28]:

$$
\mathrm{SR}=\frac{\text { Number of survived fish }}{\text { Initial number of fish }} \times 100
$$

\subsubsection{Hematological Analysis}

The blood samples of Snakehead were taken for hemoglobin, hematocrit and blood plasma analysis. Measurement of blood hemoglobin concentration was calculated using the Sahli's Method [29]. This method is relatively inexpensive, simple to use, does not require electricity and requires only small sample of blood. A haemometer tube filled with $0.1 \mathrm{~N} \mathrm{HCl}$ solution upto $2 \mathrm{~g}$ marking. Then a blood sample was taken using a $1 \mathrm{ml}$ syringe and put blood into a $20 \mu 1$ haemometer tube and mixed with pipetting. The blood was stirred and sterile distilled water was added little by little until the color of the blood solution changes to the color of the standard solution in Hb-meter. Hemoglobin concentrations were expressed in $\mathrm{g} / \mathrm{dl}$.

Measurement of hematocrit and blood plasma was done by taking a blood sample using a $1 \mathrm{ml}$ disposable syringe that has been moistened with anti-coagulant (EDTA) in Snakehead. Next, the blood is collected in a microcentrifuge tube. The blood is inserted into the hematocrit capillaries to the volume limit and covered with wax. After that, the hematocrit capillaries were centrifuged at 1000 rpm for 5 minutes. The volume of erythrocytes, leukocytes and blood plasma was measured its length with a ruler and counted for its volume percentage. Hemoglobin, hematocrit and blood plasma can be calculated using the following formulas [30].

$$
\begin{aligned}
& \text { Hematocrit }=\frac{\text { Erythrocyte }}{\text { Total blood }} \times 100 \% \\
& \text { Leukocrit }=\frac{\text { Leukocyte }}{\text { Total blood }} \times 100 \%
\end{aligned}
$$

Blood plasma $=$ amount of total blood - Leukocyte - Erythrocyte

\subsubsection{Iron ( $\mathrm{Fe}$ ) Compound}

The Fe contents in the feeds and meats of Snakehead were performed by using the Atomic Absorption Spectrophotometer (AAS) method at Industrial Standardization and Research Center of Banjarbaru. The basic principle of AAS analysis was the interaction between the radiation energy and the analyzed atomic elements. The sample solution was aspirated into a flame and the elements in the sample were converted to atomic vapor so that the flame contains the atoms of the elements to be analyzed.

\subsubsection{Water Quality}

The water quality parameters such as temperature, $\mathrm{pH}$, dissolved oxygen (DO) and $\mathrm{NH} 3$ content were also recorded during sampling periods. Observation was done at the beginning and the end of research 


\subsubsection{Length-Weight Relationship}

The length-weight relationship of Snake head finger lings was estimated by using the allometric form:

$\mathrm{W}=\mathrm{a} \mathrm{L}^{\mathrm{b}}$

Where $\mathrm{W}$ is the total weight $(\mathrm{g}), \mathrm{L}$ is the total length $(\mathrm{cm})$, a is the constant showing the initial growth index and $b$ is the slope showing growth coefficient. The $b$ exponent with a value between 2.5 and 3.5 is used to describe typical growth dimensions of relative wellbeing [31]. The $b$ value has an important biological meaning; if fish retains the same shape and grows increase isometrically $(b=3)$. When weight increases more than length $(b>3)$, it shows positively allometric. When the length increases more than weight $(b<3)$, it indicates negatively allometric [32].

\subsection{Data Analysis}

Data on parameters observed in this study were analyzed descriptively and the results were presented in graphical, verbal or in tabular form. The analysis of covariance (ANCOVA) was applied for checking any difference between treatments in term of growth pattern. One-way ANOVA test was used to ensure if any difference in the length-weight sizes of Snakehead reared in indoor containers among the four treatments. If any, then Turkey's HSD test was applied. All tests were analyzed at the 0.05 level of significance using SPSS-18 software.

\section{RESULTS AND DISCUSSION}

All estimated parameters for Snakehead fed without or with the addition of Kelakai extracts were given in Table 1.The most important result of this study was that the Kelakai extractsworked well to response immune system in Snakehead's body after they experienced stress of capture and handling during sampling period, as well as effect of high water temperature given $\left(32^{\circ} \mathrm{C}\right)$. Besides fulfilling nutritional needs, Kelakai is also potentially used as food ingredients [33], herbal medicine [34], and feed mixtures for goats [35]. According to Sholihah et al. [36], the addition of Kalakai also positively increases the iron content of baby porridge. Moreover, Kalakai extract was proven to have high average amount of antioxidant activity compare with vitamin $\mathrm{C}$ [37], inhibitory effect against Cdinduced glycation and fructation in vitro[38], and also anti-metalotoxic properties [39].

Table1. Parameters observed for Snakehead fed with different doses of Kelakai extracts

\begin{tabular}{|c|c|c|c|c|}
\hline \multirow{2}{*}{ Parameters } & \multicolumn{4}{|c|}{ Treatments } \\
\cline { 2 - 5 } & A & B & C & D \\
\hline Survival rate (\%) & 100 & 100 & 100 & 100 \\
\hline Hemoglobin (g/dl) & $7.31 \pm 4.18$ & $9.34 \pm 2.47$ & $10.32 \pm 3.29$ & $7.29 \pm 3.41$ \\
\hline Hemotocrit (\%) & $15.90 \pm 9.11$ & $18.88 \pm 7.35$ & $24.32 \pm 10.66$ & $16.02 \pm 9.02$ \\
\hline Blood plasma (g/ml) & $84.10 \pm 9.11$ & $81.12 \pm 7.35$ & $75.68 \pm 10.66$ & $83.98 \pm 9.02$ \\
\hline
\end{tabular}

\subsection{Survival Rate}

The survival rate of Snakehead fingerling samples reared in indoor containers was $100 \%$ for all treatments. This because the fingerlings were capable of consume the artificial pellets. Differ from the larval Snakehead fed with the silk worms [20]; the survival rate obtained $(97.67 \pm 2.36 \%)$ was slightly lower than our study. Meanwhile Saputra et al. [21] found that the survival rate of juvenile snakehead fed with the bloodworms ranged of 92.50-94.58\%.Snakeheadsare typically known as carnivore fish species and feeding them with the fresh Kelakai is completely useless. The addition of Kelakai extracts in artificial pellets provides the nutrition in a stable and concentrated form, enabling the fish to feed efficiently.

Besides affecting the survival rate, stress can also make fish more susceptible to infectious diseases, lose appetite, and gonad maturation delay. Stress condition induced energy utilization which belongs to grow, so that feed efficiency was low. Therefore, practical advices and field assistance related to the detection and control of stress conditions in Snakehead fish culture are needed to ensure the health of fish. The fastest way to detect the manifestation of stress in fish is the evaluation of blood parameters particularly hemoglobin, hematocrit and blood plasma. 


\subsection{Hemoglobin}

The mean and standard deviation hemoglobin concentrations of Snakehead fed with various doses of Kelakai extracts were displayed in Figure 1. The highest mean $\mathrm{Hb}$ levelwas found at treatment $\mathrm{C}$ $(10.3 \pm 23.29 \mathrm{~g} / \mathrm{dl})$, followed by treatment B $(9.34 \pm 2.47 \mathrm{~g} / \mathrm{dl})$, treatment A $(7.31 \pm 4.18 \mathrm{~g} / \mathrm{dl})$ and treatment $\mathrm{D}(7.29 \pm 3.41 \mathrm{~g} / \mathrm{dl})$. The highest mean level of Hbconcentration in the present study was slightly lower than that of Snakehead in Oseriver Nigeria [40], but it was higher than African Snakehead [41],Japanese koi carp[42] or South American fish (Pacu) in the Brazilian rivers [43].The percentage decrease in $\mathrm{Hb}$ concentration was coherently observed in Snakehead sampled after day-7 rearing period (Figure 2).

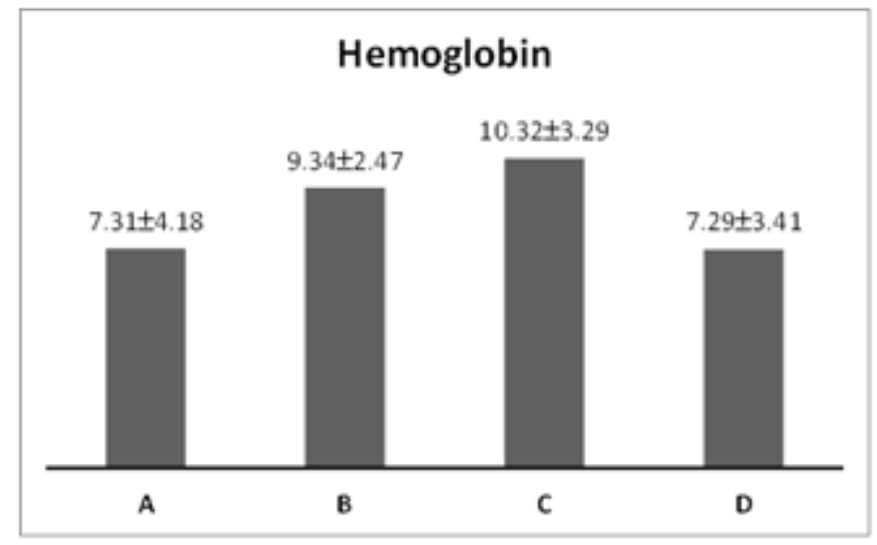

Figure1. The mean Hb concentrations $(\mathrm{g} / \mathrm{dl})$ of Snakehead fed with various doses of Kelakai extracts and mixed pellet.

\begin{tabular}{|c|c|c|c|}
\hline 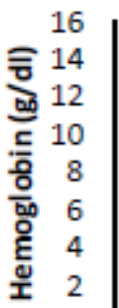 & Day-0 & Day-7 & Day-14 \\
\hline 0 & 1 & 2 & 3 \\
\hline$=\mathrm{A}$ & 11.00 & 8.13 & 2.80 \\
\hline$=\mathrm{B}$ & 12.13 & 7.73 & 8.17 \\
\hline$=\mathrm{c}$ & 13.67 & 8.20 & 9.10 \\
\hline$\longrightarrow \mathrm{D}$ & 11.80 & 4.63 & 5.43 \\
\hline
\end{tabular}

Figure2. The average Hb concentrations ( $g / d l)$ of Snakehead fed with various doses of Kelakai extracts and mixed pellet measured at different time periods.

It was mainly attributable to the change in rearing environments resulted in fish suffer from stress condition and unhealthy. The highest $\mathrm{Hb}$ percentage decrease was generated by the treatment $\mathrm{D}$ (60.73\%), followed by treatment C (40.00\%), treatment B $(36.26 \%)$ and the rest was treatment A (26.06\%).After day 14, Hb level for Snakehead fed with no Kelakai extract (treatment A) continue to decline from $8.13 \mathrm{~g} / \mathrm{dl}$ to $2.80 \mathrm{~g} / \mathrm{dl}$ or decreased by $65.57 \%$. While Snakehead fed with the addition of Kelakai extracts showed the percentage increase in its $\mathrm{Hb}$ concentrations i.e. $14.72 \%$ for treatment $\mathrm{D}$, 9.89\% for treatment $\mathrm{C}$ and $5.31 \%$ for treatment B, indicating that Kelakai extract was proven to reduce stress and increase immunity in Snake head. The high hemoglobin concentration value in Snakehead is indicative of its air-breathing character. Physiologically, hemoglobin is crucial to the survival of the fish as its role is directly related to the oxygen binding capacity of blood.

\subsection{Hematocrit}

Figure 3 shows the percentages of hematocrit value (Hct) sourced from the blood samples of Snakehead fed with different doses of Kelakai extracts. The highest percentageof Hct level was given 
by treatment C $(24.32 \pm 10.66 \%)$, followed by treatment B $(18.88 \pm 7.35 \%)$, treatment D (16.02 \pm $9.02 \%)$ and treatment A $(15.90 \pm 9.11 \%)$. The Hct value apparently reproduced erythrocyte hemolysis and the Hctvalue $(24.32 \%)$ was 2.4 times the value of haemoglobin $(10.32 \mathrm{~g} / \mathrm{dl})$.The highest percentage of Hct level in our finding was comparatively higher than that of African Snakehead [41], but it was lower compared to the Pacu in the Brazilian rivers [43]. Low hematocrit value resulted in fish usually stop feeding [44].

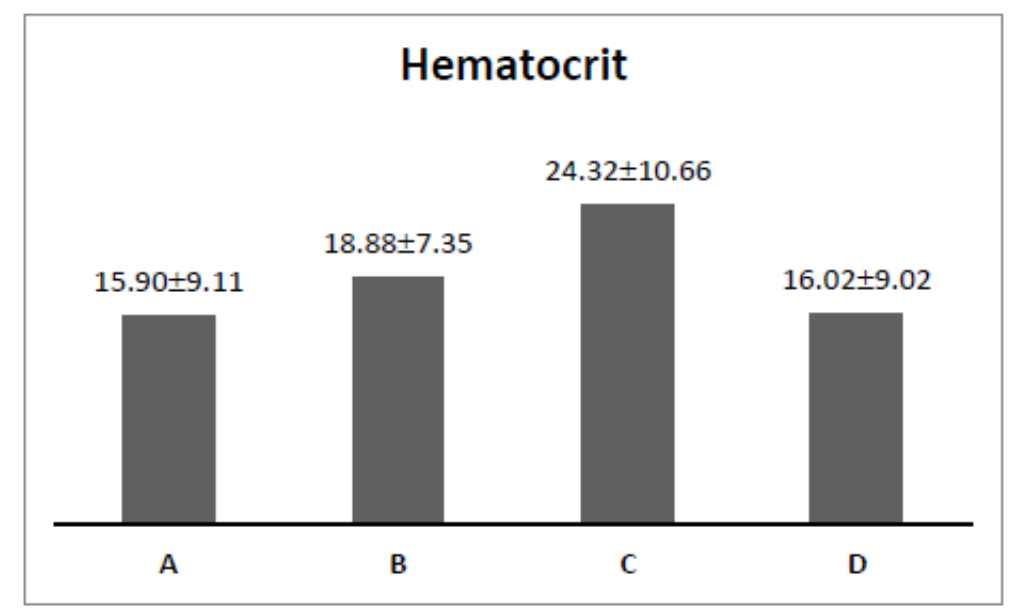

Figure3. The percentages of Hematocrit taken from the blood samples of Snakehead fed with various doses of Kelakai extracts in the mixed pellet.

\subsection{Blood Plasma}

Blood plasma values in fish are inversely proportional to the hematocrit values. If the hematocrit value increased, the blood plasma value decreased. Variation in blood plasma values is also affected by the physiological conditions of fish. The lower blood plasma the stronger the fish immune system and the addition of Kelakai extracts had positively contributed to the immune-triggering response in Snakehead. The highest concentration of blood plasma was observed in treatment A $(84.10 \pm 9.11$ $\mathrm{g} / \mathrm{ml})$, followed by treatment $\mathrm{D}(83.98 \pm 9.02 \mathrm{~g} / \mathrm{ml})$, treatment $\mathrm{B}(81.12 \pm 7.35 \mathrm{~g} / \mathrm{ml})$ and the lowest level was treatment $C(75.68 \pm 10.66 \mathrm{~g} / \mathrm{ml})$. The ratios of hematocrit to the blood plasma concentrations for treatment $\mathrm{B}$ and $\mathrm{C}$ were 1.2 and 1.7 times higher than those for treatment $\mathrm{A}$.

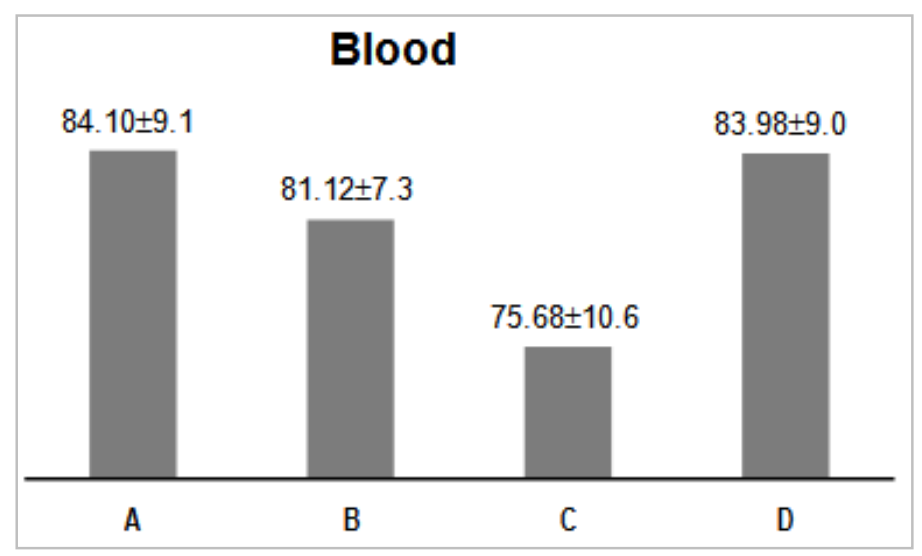

Figure4. The blood plasma $(\mathrm{g} / \mathrm{ml})$ of Snakehead fed with various doses of Kelakai extract in the mixed pellet.

\subsection{Iron ( $\mathrm{Fe})$ Compound}

Hemoglobin is the iron-containing oxygen-transport metalloprotein that is present in the red blood cells of all vertebrates[45]. The recommended dietary allowance (RDA) for iron is $10-20 \mathrm{mg} / \mathrm{day}$, but the only 1-2 $\mathrm{mg}$ of iron is able to be absorbed by the fish body. Ironis needed for proper immune function and also used for energy to generate metabolism system in the fish body.In present study, the Fe compound in the tested feeds for Snakehead fingerlings ranged from 24.35 to $28.01 \mathrm{mg} / \mathrm{kg}$. While the iron concentration in the fish meat falls between 1.76 and $3.08 \mathrm{mg} / \mathrm{kg}$ or about $6.28-11.40 \%$ of tested feed given (Table 2). 
Effectiveness of the Addition of Kelakai (Stenochlaena palustris) Extracts in Commercial Pellet as Immunostimulant for Snakehead (Channa striata)

Table2. Comparison ofiron compound in the tested feedsand fish meats of Snakehead fingerlings.

\begin{tabular}{|c|c|c|}
\hline Treatments & Tested Feed $(\mathrm{mg} / \mathrm{kg})$ & Fe in fish meat $(\mathrm{mg} / \mathrm{kg})$ \\
\hline A & 27.01 & 3.08 \\
\hline B & 25.41 & 2.41 \\
\hline C & 28.01 & 1.76 \\
\hline D & 24.35 & 2.34 \\
\hline
\end{tabular}

\subsection{Length-Weight Relationship}

The body shape of Snakehead fingerlings in treatments A, B and C showed negative allometric growth pattern $(b=1.89-2.48)$, while for treatment $\mathrm{D}$ exhibited isometric growth pattern $(b=2.96)$. The length-weight relationships for treatment A-D were expressed in the following equations: $\mathrm{W}=$ $0.0387 \mathrm{TL} 2.48, \mathrm{~W}=0.2071 \mathrm{TL} 1.89, \mathrm{~W}=0.0828 \mathrm{TL} 2.22$ and $\mathrm{W}=0.0096 \mathrm{TL} 2.96$ respectively. The determination coefficient (R2) values ranged of $0.479-0.844$ indicating that more than $80 \%$ of variability of the weight is explained by the length. The regression correlation(r) falls between 0.692 and 0.919 , found to be higher than 0.5 , showing the length-weight relationship is positively correlated.

A negative allometric growth pattern in the present study has also been reported for C. striata from Agusan Marsh, Philippines [7], C. diplogramma from Lake Vembanad, India [6],C. limbata from Ta Bo - HuaiYai Wildlife Sanctuary, Thailand[46] and C. obscura from Ologe Lagoon, Nigeria [47]. Our finding was contrary to C. striatus from Uttar Pradesh, India [5]; C. punctata from Gomti River, India [48] and Parachannaobscura from Buyo reservoir, West Africa [49], in which exhibited positive allometric growth pattern (b>3). Meanwhile, C. punctatus from Gomti River, India was reported to have isometric growth pattern [50]. Variation in slope may also be attributed to life stages and environmental factors such as food and space [13]. There was no significant difference in the weight size of Snakehead reared among the four treatments $(\mathrm{P}>0.05)$; however, the length size of Snakehead in treatment $\mathrm{C}$ was comparatively higher than that of treatment $\mathrm{D}(\mathrm{P}<0.05)$.

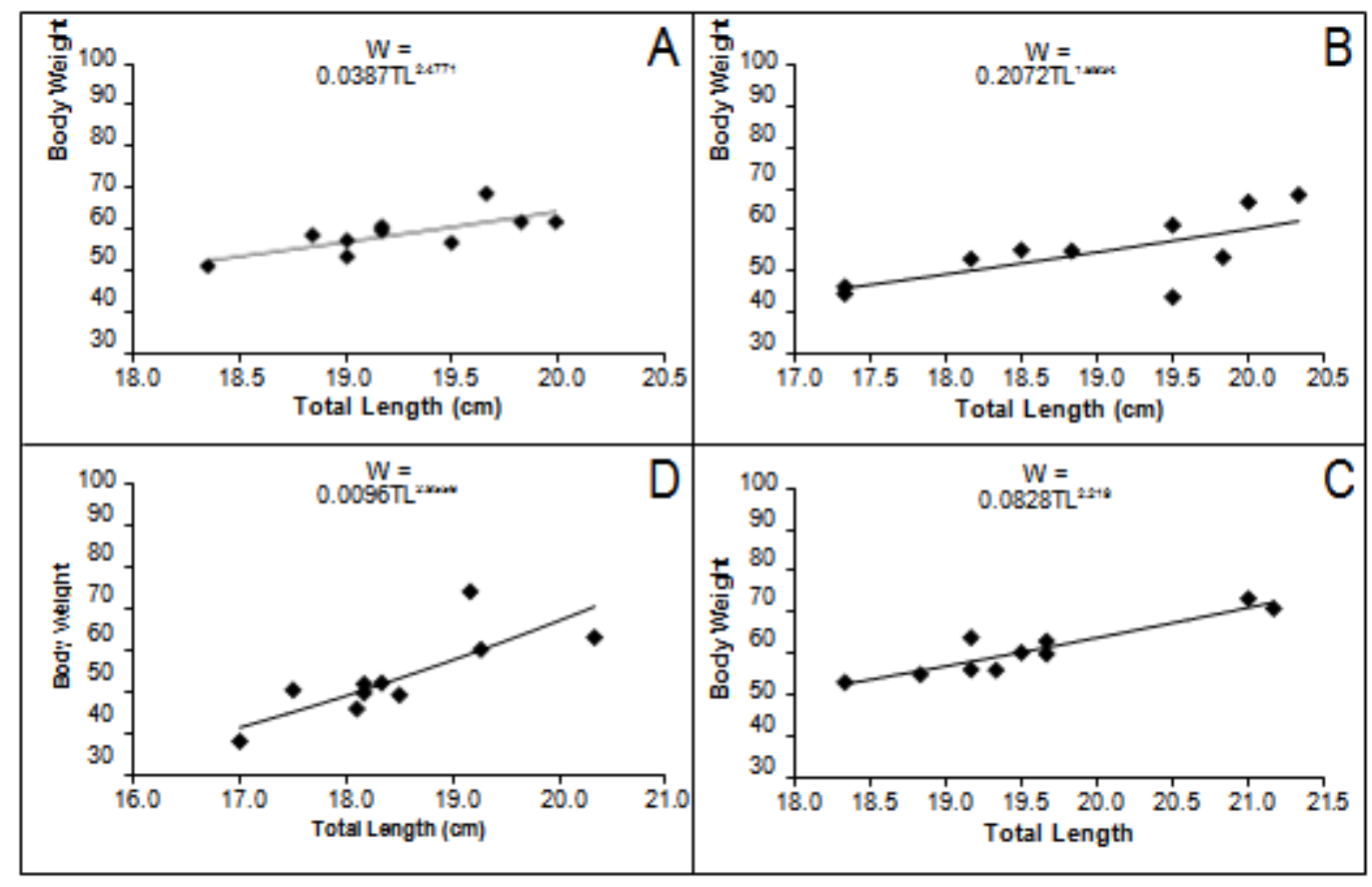

Figure5. The length-weight relationships of Snakehead fed with the commercial pellet without Kelakai extract (A) and with the addition ofKelakai extracts $50 \mathrm{ml} / \mathrm{kg}(B), 100 \mathrm{ml} / \mathrm{kg}(C)$ and $150 \mathrm{ml} / \mathrm{kg}$ respectively.

\subsection{Water Quality}

Stress in fish is caused by many different factors including extreme environmental changes. Improper temperature, high or low $\mathrm{pH}$, low oxygen levels, high ammonia or nitrate levels can cause stress. Water quality parameters measured throughout experimental period were summarized in Table 3. Water temperature and $\mathrm{pH}$ ranged of $26.5-27.1^{\circ} \mathrm{C}$ and 6.3-6.7 respectively. The DO of 4.1-5.1 ppm measured in place was within the optimum DO range required for the fish in general (4-8 ppm); while the 
ammoniac content ranged of 1.20-2.88 mg/l.The values of water quality parameters in the containers between treatments showed no significant difference, and it was in tolerance range for Snakehead fingerlings to growth out.

Tabel 3. Water quality parameters measured for Snakehead during the rearing periods

\begin{tabular}{|c|c|c|c|c|}
\hline \multirow{2}{*}{ Parameter } & \multicolumn{4}{|c|}{ Treatments } \\
\cline { 2 - 5 } & $\mathrm{A}$ & $\mathrm{B}$ & $\mathrm{C}$ & $\mathrm{D}$ \\
\hline Temperature $\left({ }^{\circ} \mathrm{C}\right)$ & $26.5-26.7$ & $26.5-27.1$ & $26.5-26.6$ & $26.5-26.6$ \\
\hline $\mathrm{pH}$ & 6.5 & 6.7 & 6.3 & 6.4 \\
\hline $\mathrm{DO}(\mathrm{ppm})$ & 4.9 & 5.1 & 4.1 & 4.1 \\
\hline $\mathrm{NH} 3(\mathrm{mg} / \mathrm{l})$ & 1.44 & 1.88 & 1.20 & 1.26 \\
\hline
\end{tabular}

\section{CONCLUSION}

It can be scientifically proven that the addition of Kelakai extracts in artificial pellets positively contributes to the immune-triggering response in Snakehead indicated by the corresponding values of higher $\mathrm{Hb}$ and Hct levels in its blood samples. The outcome of research could be useful for fish farming management system and pellet industry.

\section{ACKNOWLEDGEMENT}

Our gratitude goes to the Head of Peatland Fish Farming Installation of PulangPisau District, the Head of Water Quality Laboratory Faculty of Marine and Fisheries, LambungMangkurat University, and also the Head of Industrial Standardization and Research Center of Banjarbaru. Author thanks reviewers for significantly improving the contents of manuscript to publishable level.

\section{REFERENCES}

[1] Ahmadi. (2019). Morphometric characteristic and growth patterns of Climbing perch (Anabas testudineus) from Sungai Batang River, Indonesia.International Journal of Hydrology. 4(3): 270-277.

[2] KhairulAdha A. R., Esa, Y. and Arshad, A. (2013). The influence of alien fish species on native fish community structure in Malaysian waters.Kuroshio Science. 7(1): 81-93.

[3] Xie, H., Lü, X., Zhou, J., Shi, C., Li, Y., Duan, T., Li, G. and Luo, Y. (2017). Effects of acute temperature change and temperature acclimation on the respiratory metabolism of the snakehead.Turkish Journal of Fisheries and Aquatic Sciences. 17: 535-542.

[4] Amilhat E. andLorenzen K. (2005). Habitat use, migration pattern and population dynamics of chevron snakehead Channastriatain a rainfed rice farming landscape.Journal of FishBiology. 67(Suppl. B): 23-34.

[5] Dayal, R., Srivastava, P.P., Bhatnagar, A., Chowdhary, S., Lakra, W.S., Raizada, S. and Yadav, A.K. (2012). Comparative study of WLR of Channastriatus of fry-fingerling, grow-outs and adults of gangetic plains. Online J. Anim. Feed Res., 2(2): 174-176.

[6] Ali, A., Dahanukar, N. andRaghavan, R. (2013). Length-weight and length-length relationship of three species of snakehead fish, Channadiplogramma, C. maruliusand C. striatafrom the riverine reaches of Lake Vembanad, Kerala, India.Journal of Threatened Taxa. 5(13): 4769-4773.

[7] Jumawan, J.C. and Seronay, R.A. (2017). Length-weight relationships of fishes in eight floodplain Lakes of Agusan Marsh, Philippines.Philippine Journal of Sciences. 146(1): 95-99.

[8] He, D., Li, G., Xie, H., Liu, S. and Luo, Y. (2015). Effects of feeding frequency on the post-feeding oxygen consumption and ammonia excretion of the juvenile snakehead.Turkish Journal of Fisheries and Aquatic Sciences. 15(2): 295-303.

[9] Quyen, N.T.K., Minh, T.H., Hai, T.N., Hien T.T.T. and Dinh, T.D. (2016). Technical-economic efficiencies of snakehead seed production under impacts of climate change in the Mekong Delta, Vietnam. Anim. Rev.,3(4): 73-82.

[10] Haiwen, B., Shaoyu, H., Lwin, U.T., Swe, U.T., Qiufen, D., Song, Z. and Yong. Y. (2014). The Snakehead Fish: a Success in Myanmar. AQUA Culture Asia Pacific Magazine.20-23 p.

[11] Darda, K., Mahyudin, I., Mahreda, E.S. and Fitriliyani, I. (2019). The impacts of Striped Snakehead (Channastriata Bloch) fish farming in net cages on social, economic and environmental aspects in Bangkau Village, Hulu Sungai Selatan. International Journal of Environment, Agriculture and Biotechnology. 4(2): 392-396

[12] Courtenay, W.R.Jr. and Williams, J.D. (2004). Snakeheads (Pisces: Channidae): A biological synopsis and risk assessment. United States Geological Survey, Gainesville, FL, USA, 143 pp. 
[13] Lapointe, N.W.R., Odenkirk, J.S. and Angermeier, P.L. (2013). Seasonal movement, dispersal, and home range of northern snakehead Channaargus(Actinopterygii, Perciformes) in the Potomac river catchment. Hydrobiologia. 709: 73-87.

[14] Uthayakumar, V., Chandirasekar, R., Sreedevi, P.R., Senthilkumar, D., Jayakumar, R. and Ramasubramanian, V. (2014). Immunostimulatory effect and disease resistance induced by Lawsoniainermis against Aphanomycesinvadansin Striped Murrels (Channastriatus). Malaya Journal of Biosciences. 1(4): 231-241

[15] Sofarini,D., Mahmudi,M., Hertika,A.M.S .and Herawati,E.Y.(2018). Dinamika populasi ikan Gabus (Channastriata) in Rawa Danau Panggang, Kalimantan Selatan. EnviroScienteae. 14(1): 16-20

[16] Ramli, H.R. and Rifa'i, M.A. (2010). Telaah food habits, parasit, dan bio-limnologifase-fase kehidupan ikanGabus (Channastriata) di PerairanUmum Kalimantan Selatan. Ecosystem.2(10): 76-84.

[17] Asuwaju, F.P., Onyeche, V.O., Ogbuebunu, K.E., Moradun, H.F.and Robert, E.A. (2014). Effect of feeding frequency on growth and survival rate of Clariasgariepinusfingerlings reared in plastic bowls. Journal of Fisheries and Aquatic Science. 9(5): 425-429.

[18] Roy, N.C., Chowdhury, S.K. and Das, S.K. (2016). Observation of hapa breeding technique of striped snakehead, Channastriatus (Bloch, 1793) under captive conditions.International Journal of Fisheries and Aquatic Studies. 4(5): 413-417.

[19] Bijaksana, U., Hidayaturrahmah, and Dewi, K.S. (2015). Restocking' model of snakehead farming, Channa striataBlkr in Bangkau swamp of South Kalimantan Province. Global Journal of Fisheries and Aquaculture 3(2): 198-204.

[20] Mahardika, S., Mustahal, Indaryanto, F.R. and Saputra, A. (2017). Growth and survival rate of the Snakehead (Channastriata) larvae fed with different natural feeds. Jurnal Perikanan dan Kelautan. 7(1): 82-92.

[21] Saputra, A., Budiardi, T., Samsudin, R. and Rahmadya, N.D. 2018. Growth performance and survival of snakehead Channastriata juvenile with different stocking density reared in recirculation system. JurnalAkuakultur Indonesia. 17(2): 104-112

[22] Anwar, K., Bijaksana, U., Herliwati, and Ahmadi.(2018). Oodev injection frequency and time period in advancing gonad rematuration of Snakehead (Channa striata Blkr) in hapa system.Int. J. Envi. Agri. Biotechnol. 3(3): 1114-1122.

[23] Ahmadi. (2018). The length-weight relationship and condition factor of the threatened Snakehead (Channastriata) from Sungai Batang River, Indonesia. Polish Journal of Natural Sciences.33(4):607-623.

[24] Javed, M., Irshad Ahmad, I., Ahmad, A., Usmani, N. and Ahmad, M. (2016). Studies on the alterations in haematological indices, micronuclei induction and pathological marker enzyme activities in Channapunctatus(Spotted snakehead) perciformes, channidae exposed to thermal power plant effluent.SpringerPlus. 5(761): 1-9.

[25] Ho, R., Teai, T., Bianchini, J.P., Lafont, R. and Rahariveloma-nana, P. (2010). Ferns: From traditional uses to pharmaceutical development, chemical identification of active principles. In H. Fernández, M.A. Revilla, and A. Kumar (eds.), Working with ferns: Issues and applications. Springer, New York, pp. 321-346.

[26] Margono, D.P.N.H., Suhartono, E. and Arwati, H. (2016).Potensi ekstrak Kelakai (Stenochlaenapalustris (Burm.f) Bedd) terhadapkadar Tumor Necrosis Factor-Alfa (TNF- $\alpha$ ) padaMencitBalb/c yang diinfeksiPlasmodium bergheiANKA.BerkalaKedokteran. 12(1): 77-85

[27] Tahir,B, Shaleh,C. and Pasaribu,S.P.(2013). Ujifitokimia, toksisitas dan aktivitas antioksidan alami dari tumbuhan Kelakai (Stenochlaenapalustris) denganmetode DPPH.Prosiding Seminar Nasional Kimia 2013.pp.141-146.

[28] Yousuf, A.H.M., Hossain, M.S. and Hossain, M.B. (2016). Effects of different feeding trial in the proximate composition of shoal fish (Channastriatus) cultured in glass aquaria. World Journal of Fish and Marine Sciences. 8(1): 54-63

[29] Kapil, U., Tandon, M., Pathak, P. and Dwived, S.V. (2012). Comparison of hemoglobin values obtained by Hemocue and Sahli's methods.Indian Journal of Public Health. 46(1): 28-30.

[30] Anderson, D.P. and Siwicki,A.K. (1994). Simplified assay for measuring nonspecific defense mechanism in fish. Fish Health Section/American Fisheries Society Meetings.Seatle, Woshington. 1-26 pp.

[31] Bagenal, T. (1978). Methods for assessment of fish production in freshwaters.3rd ed. Blackwell Scientific Publication. Oxford, London, p. 365.

[32] Froese, R. (2006). Cube law, condition factor and weight-length relationships: history, meta-analysis and recommendations. Journal of Applied Ichthyology. 22: 241-253. 
[33] Rahmawati, D., Rifky, N.A. andMarpaung, A.M. (2017). Extraction and stability analysis of antioxidant activity from Stenochlaenapalustris. Proceedings: International Postgraduate Symposium on Food, Agriculture and Biotechnology, pp. 45-52

[34] Awang-Kanak, F. and Abu Bakar, M.F. (2020). Traditional vegetable salad (ulam) of Borneo as source of functional food.Food Research. 4(1): 1-12.

[35] Jaelani, A., Malik, A., Nimah, G.K. and Djaya, M.S. (2019). Comparison of swamp forages on complete granule feeds to nutrition content and digestibility. ZIRAA'AH. 44(1): 115-120

[36] Sholihah, N.M., Agustina, L. andNugroho, A. (2018). Formulation of baby porridge flour using Nagara Tuber and Kalakai (Stenochlaenapalustris) as iron fortifying agent with natural flavor of Ambon Banana.Jurnal Riset Industri Hasil Hutan. 10(2): 75-82.

[37] Bayliak, M.M., Burdyliuk, N.I. and Lushchak, V.I.(2016). Effects of $\mathrm{pH}$ on antioxidant and prooxidant properties of common medicinal herbs.Open Life Science Journal.DOI: https://doi.org/10.1515/biol-2016-0040

[38] Suhartono, E., Bahriansyah, M. andTriawanti. (2016). Theinhibition effect of Kelakai (Stenochlaenapalustris) extract on Cadmium-induced Glycation and Fructationin-vitro. International Journal of Pharmaceutical and Clinical Research. 8(4): 248-253.

[39] Biworo, A., Azizi, N.A., Padelia, R., Raharja, M.A., Azima, O. and Suhartono, E. (2018). AntiMetalotoxic properties of Kelakai (Stenochlaenapalustris)leaves extract against Camium-induced liver tissue damage. Asian Journal of Pharmaceutical and Clinical Research. 11(3): 43-46.

[40] Odedeyi, D.O. (2013). Seasonal, sex and size variation in some blood parameters of Snakehead fish (Parachannaobscura, Gunther 1861) in Ose River, Southwest-Nigeria.Global Journal of Biology, Agriculture and Health Sciences. 2(4): 107-110.

[41] Kori-Siakpere, O., Ake, J.E.G. and Idoge, E. (2005). Haematological characteristics of the African snakehead, Parachannaobscura.African Journal of Biotechnology. 4(6): 527-530.

[42] Radu, D., Oprea, L., Bucur, C., Costache, M. and Oprea, D. (2009). Characteristics of haematological parameters for Carp culture and Koi (CyprinuscarpioLinneaus, 1758) reared in an intensive System.Bulletin UASVM Animal Science and Biotechnologies. 66(1-2): 336-342.

[43] Jerônimo, G.T., Pádua, S.B., Bampi, D., Gonçalves, E.L.T., Garcia, P., Ishikawa, M.M. and Martins, M.L. (2014). Haematological and histopathological analysis in South American fish Piaractusmesopotamicus parasitized by monogenean (Dactylogyridae).Brazilian Journal of Biology. 74(4): 1000-1006.

[44] Talpur, A.D. andIkhwanuddin, M.(2013). Azadirachta indica(neem) leaf dietary effects on the immunity response and disease resistance of Asian seabass, Latescalcariferchallenged with Vibrio harveyi. Fish and Shellfish Immunology. 34:254-264.

[45] Jagadeesan, G., Malathy, P., Gunasekaran, K., HarikrishnaEtti, S. and Aravindhan, S. (2014). Purification, crystallization, preliminary X-ray diffraction and molecular-replacement studies of great cormorant (Phalacrocoraxcarbo) haemoglobin.Acta Crystallographica.F70: 1526-1528.

[46] Khomsab, K. and Wannasri, S. (2017). Biological Aspects of Channalimbata (Cuvier, 1831) in Ta Bo HuaiYai Wildlife Sanctuary, Phetchabun Province, Thailand.SainsMalaysiana. 46(6): 851-858.

[47] Kumolu-Johnson, C.A. and Ndimele, P.E. (2010). Length-weight relationships and condition factors of twenty-one fish species in Ologe Lagoon, Lagos, Nigeria. Asian J. Agri. Sci., 2(4): 174-179.

[48] Singh, M. and Serajuddin, M.(2017). Length-weight, length- length relationship and condition factor of Channa punctatus collected from three different rivers of India. J. Entomol. Zool. Stud., 5(1): 191-197.

[49] Tah, L., Gouli Bi, G. and Da Costa, K.S. (2012). Length-weight relationships for 36 freshwater fish species from two tropical reservoirs: Ayame I and Buyo, Cote d'Ivoire. Rev. Biol. Trop. (Int. J. Trop. Biol.). 60(4): 1847-1856.

[50] Kashyap, A., Awasthi, M. and Serajuddin, M. (2014). Length-weight and length-length relationship of freshwater Murrel, Channapunctatus(Bloch, 1793) sampled from river Gomti in Lucknow region (Uttar Pradesh). World Journal of Fish and Marine Sciences. 6(4): 336-339.

Citation: Norhayati, et.al, "Effectiveness of the Addition of Kelakai (Stenochlaena palustris) Extracts in Commercial Pellet as Immunostimulant for Snakehead (Channa striata)". International Journal of Innovative Studies in Aquatic Biology and Fisheries, 6(1), pp.8-17. http://dx.doi.org/10.20431/2454-7670.0601002

Copyright: () 2020 Authors. This is an open-access article distributed under the terms of the Creative Commons Attribution License, which permits unrestricted use, distribution, and reproduction in any medium, provided the original author and source are credited. 